\title{
Individual and Combined Application of Nematophagous Fungi as Biological Control Agents against Gastrointestinal Nematodes in Domestic Animals
}

\author{
Shuoshuo Li ${ }^{1,2}$, Da Wang ${ }^{1,2}$, Jianchuan Gong ${ }^{1,2}$ and Ying Zhang ${ }^{1, *(D)}$ \\ 1 State Key Laboratory for Conservation and Utilization of Bio-Resources in Yunnan, \\ Key Laboratory for Southwest Microbial Diversity of the Ministry of Education, Yunnan University, \\ Kunming 650032, China; lishuoshuo@mail.ynu.edu.cn (S.L.); wangdawangda@mail.ynu.edu.cn (D.W.); \\ gongyusheng@mail.ynu.edu.cn (J.G.) \\ 2 School of Life Science, Yunnan University, Kunming 650032, China \\ * Correspondence: yingzhang@ynu.edu.cn
}

check for

updates

Citation: Li, S.; Wang, D.; Gong, J.; Zhang, Y. Individual and Combined Application of Nematophagous Fungi as Biological Control Agents against Gastrointestinal Nematodes in Domestic Animals. Pathogens 2022, 11, 172. https://doi.org/10.3390/ pathogens11020172

Academic Editor: Jackson Victor de Araújo

Received: 25 December 2021

Accepted: 25 January 2022

Published: 27 January 2022

Publisher's Note: MDPI stays neutral with regard to jurisdictional claims in published maps and institutional affiliations.

Copyright: (C) 2022 by the authors. Licensee MDPI, Basel, Switzerland. This article is an open access article distributed under the terms and conditions of the Creative Commons Attribution (CC BY) license (https:// creativecommons.org/licenses/by/ $4.0 /)$.

\begin{abstract}
Gastrointestinal nematodes (GINs) are a group of parasites that threaten livestock yields, and the consequent economic losses have led to major concern in the agricultural industry worldwide. The high frequency of anthelmintic resistance amongst GINs has prompted the search for sustainable alternatives. Recently, a substantial number of both in vitro and in vivo experiments have shown that biological controls based on predatory fungi and ovicidal fungi are the most promising alternatives to chemical controls. In this respect, the morphological characteristics of the most representative species of these two large groups of fungi, their nematicidal activity and mechanisms of action against GINs, have been increasingly studied. Given the limitation of the independent use of a single nematophagous fungus (NF), combined applications which combine multiple fungi, or fungi and chemical controls, have become increasingly popular, although these new strategies still have antagonistic effects on the candidates. In this review, we summarize both the advantages and disadvantages of the individual fungi and the combined applications identified to date to minimize recurring infections or to disrupt the life cycle of GINs. The need to discover novel and highefficiency nematicidal isolates and the application of our understanding to the appropriate selection of associated applications are discussed.
\end{abstract}

Keywords: predatory fungi; ovicidal fungi; gastrointestinal nematodes (GINs); chemical anthelmintic drugs; nematicidal activity

\section{Introduction}

Nematodes are the most abundant animals on Earth, with approximately $4.4 \pm 0.64 \times$ $10^{20}$ individuals inhabiting the upper layer of soils across the globe [1,2]. The species diversity of the terrestrial nematode community is high, but most members lack the ability to decompose organic matter [3]. Thus, feeding habits are fundamental in their nutrient cycles and provide the basis for definitions of the essential feeding types of terrestrial nematodes. The following groups of hosts are recognized: animals, plants, fungi, bacteria, and unicellular eukaryotes [4]. With professional helminths being among them, animal- and plant-parasitic nematodes contribute to great economic losses to agriculture worldwide. Gastrointestinal helminth parasites, which are harmful to animal health, have a significant impact on the productivity and quality of livestock [5-7]. The successful control of helminths relies heavily on their disruption across the entire life cycle.

The life cycle of gastrointestinal parasitic nematodes in animals consists of two stages: (1) in the endogenous stage, the adults (the fourth or fifth larval stage; L4/L5) are parasitic in the gastrointestinal tracts (GT) of animals, and (2) in the exogenous stage, the infected adults are excreted from the animal and develop into eggs and larvae in the feces, where 
the larvae go through their first and second larval stages and enter the infective third larval stage (L3); subsequently, free-living nematodes (eggs, larvae, cysts) integrate into pasture and are ingested by livestock during grazing, which leads to recurrent infection by nematodes [8-11] (Figure 1). As a matter of fact, epidemiological studies have indicated that only $5 \%$ of gastrointestinal nematodes (GINs) are located within animals, while $95 \%$ live on pasture in the form of eggs and larvae [12-14]. Therefore, it is necessary to focus on the control of nematodes at the exogenous stage so as to minimize recurrent infections [15-17]. In order to control nematodes more efficiently, it is important to interfere with their entire life cycle - that is, to reduce the numbers of nematodes in animals and on the pasture at the same time.

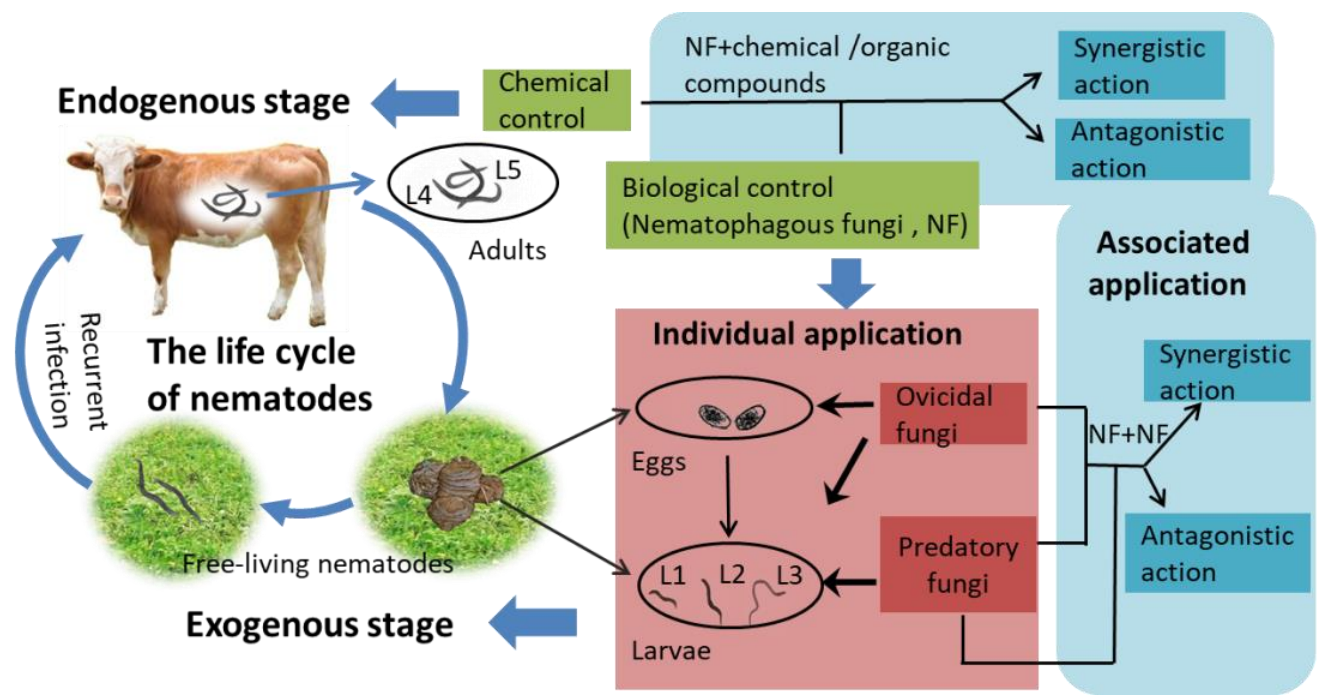

Figure 1. The life cycle of gastrointestinal nematodes (GINs) includes exogenous and endogenous stages. The application of individual fungi is used to eliminate exogenous nematodes, and the combined application of multiple fungi or fungi and chemical controls is used to eliminate endogenous nematodes.

Chemical controls are the traditional method used for reducing GINs, but the frequently reported disadvantages of this method include the development of resistance in the nematodes and the potential risk to human health from nematode contamination of the environment via the residue in animal products and feces [18-20]. However, nematophagous fungi (NF), as natural enemies of gastrointestinal helminth parasites, shape as the alternative to chemical controls with the most potential; they can be used to control the immature nematodes present in animal feces [21,22]. In recent years, biological controls have become an important research area in the control of helminths due to the absence of the disadvantages of chemical controls and conformity to the goals of ecological sustainability [23-25]. Predatory and ovicidal NF fungi have been shown in extensive in vitro and in vivo tests to effectively reduce recurrent infections by GINs in domestic animals [26]. However, in order to further enhance nematicidal activity, current studies now employ new strategies with combined applications of multiple fungi or fungi and chemical controls to minimize recurring infections or to disrupt the whole life cycle of nematodes [27] (Figure 1). Until recently, individual agent application was the mainstream solution to controlling nematode populations, while combined applications were an auxiliary method, because the incompatibility and inefficiency of the latter could not be ignored.

This review concentrates on the latest research in which NF are viewed as the most promising biocontrol agents of GINs in domestic animals. We have collected and commented on the literature related to combined applications and explained that such a strategy can have an additive effect under some circumstances. Aiming at the application of NF for domestic animal GIN infection, this review outlines the need to discover novel and high-efficiency nematicidal isolates and the need to choose a combined application when 
application of a single solution is ineffective. This new strategy may serve as a complementary method for biological control and provide a new research direction for future GIN management.

\section{The Most Representative Biocontrol Candidates-Individual Application}

NF are divided into five groups: predatory, opportunistic or ovicidal, endoparasitic, toxin-producing, and producers of special attack devices [28,29], but most studies on the biological control of GINs have been restricted to the two traditional groups of NF: predatory fungi and ovicidal fungi. To date, numerous experiments, both in vivo and in vitro, have verified that the representative species of the two NF have common advantages in individual application: (1) no loss of predatory viability as they pass through the GTs of animals; (2) the effective reduction of immature-stage nematodes, including eggs and larvae; (3) a strong ability to germinate spores in feces.

\subsection{Predatory Fungi}

Predatory fungi are a key tool in killing nematodes. They produce modified hyphae called traps, which can be either adhesive trapping devices (network, hyphae, branches, knobs) or non-adhesive trapping devices (non-constricting or constricting rings) [30,31]. These traps bind and digest both adult and larval nematodes via mechanical or enzymatic processes [32]. Lysek and Araújo et al. found that this group of fungi only showed physiological effects; hyphae adhered to the eggshells of helminths without egg destruction $[33,34]$. Therefore, the use of these fungi may have low efficiency, because undamaged eggs can cause recurrent infections [24]. There is, however, no doubt that the effect of predatory fungi on the larvae of GINs is satisfactory. According to the most recent taxonomic classification, all predatory orbiliaceous fungi are assigned into three genera-Arthrobotrys, Drechsleralla, and Dactylellinabased on the use of trapping devices as the primary criterion for generic delimitation [35,36]. However, the old species names also appeared in the literature studied in this review.

\subsubsection{Duddingtonia}

The genus Duddingtonia possesses an outstanding characteristic in that it produces numerous chlamydospores, a type of thick-walled spore [37]. These spores have a shape that can range from elliptical to ovoid with a median septum [38]. The production of abundant chlamydospores is an advantage, because abundant fungal spores are an important strategy for survival and spread. Consequently, this group of fungi is more successful than other genera in the control of nematodes [39].

Duddingtonia flagrans is one of the most widely studied and most promising species. Its chlamydospores can withstand gastrointestinal transportation and other undesirable environments to germinate, forming as a predator device a three-dimensional network structure to capture living larvae in animal feces $[37,40]$. Experimental studies in vitro have shown that $D$. flagrans could reduce up to $96.4 \%$ of GINs, better than Monacrosporium thaumasium and Arthrobotrys robusta [41,42], and in in vivo tests a reduction of $55.15 \%-98.82 \%$ has been reported [43]. With the development of next-generation sequencing, genomic analysis of $D$. flagrans has shown that the species contains more abundant genes relating to the pathogenicity of nematodes than other fungi, such as cytochrome P450 genes and proteasecoding genes, which provide $D$. flagrans with stronger nematicidal activity and keep other enemies (such as fungal-feeding nematodes) from feeding [44,45]. Moreover, D. flagrans has fewer carbohydrate-degradation-related genes and a weaker saprophytic capability than other fungi, which makes $D$. flagrans rely on nematodes as its sole nutrition source, which is associated with its excellent ability to form traps $[44,46]$. To date, $D$. flagrans has been viewed as a good controller of trichostrongylides and cyathostome (the most prevalent GINs in livestock) in various domestic animals (Table 1). Bioverm ${ }^{\circledR}$, a fungal formulation that contains chlamydospores of $D$. flagrans, has been licensed for commercialization in Brazil $[17,47]$. 
Table 1. In vivo tests and in vitro nematicidal tests with nematophagous fungi of the genera Duddingtonia, Arthrobotrys, and Monacrosporium on the gastrointestinal nematodes of domestic animals.

\begin{tabular}{|c|c|c|c|c|c|}
\hline \multirow{2}{*}{ Fungi } & \multirow{2}{*}{ GIN Species } & \multirow{2}{*}{ Dose } & \multicolumn{2}{|c|}{ Nematicidal Activities } & \multirow{2}{*}{ Reference } \\
\hline & & & In Vivo Test & In Vitro Test & \\
\hline A. cladodes & $\begin{array}{l}\text { Haemonchus sp., Cooperia sp., } \\
\text { Oesophagostomum sp. (cattle) }\end{array}$ & $\begin{array}{l}1 \mathrm{~g} \text { pellets } / 10 \mathrm{~kg} \mathrm{BW}, \\
\text { twice a week }\end{array}$ & $52-59 \%$ & $68.7 \%$ & {$[48,49]$} \\
\hline A. oligospora & $\begin{array}{l}\text { H. contortus, T. colubriformis } \\
\text { (sheep) }\end{array}$ & $\begin{array}{l}5 \times 10^{5} \text { spores } / \mathrm{kg} \mathrm{BW} \\
2 \mathrm{~mL} \text { fungal suspension }\end{array}$ & $53.88-97.26 \%$ & $90-99.99 \%$ & {$[50]$} \\
\hline $\begin{array}{l}\text { A. conoides, } \\
\text { A. sinense }\end{array}$ & trichostrongylides (sheep) & $\begin{array}{l}5 \times 10^{5} \text { spores } / \mathrm{kg} \mathrm{BW} \\
2 \mathrm{~mL} \text { fungal suspension }\end{array}$ & $\begin{array}{l}37.84-78.64 \% \\
54.49-86.93 \%\end{array}$ & $\begin{array}{l}80.00-97.41 \%, \\
97.02-98.49 \%\end{array}$ & [18] \\
\hline A. superba & Haemonchus contortus (sheep) & $\begin{array}{l}5 \times 10^{5} \text { spores } / \mathrm{kg} \mathrm{BW} \\
2 \mathrm{~mL} \text { fungal suspension }\end{array}$ & $83.79 \%$ & $86.48-97.69 \%$ & [19] \\
\hline $\begin{array}{l}\text { A. musiformis, } \\
\text { A. robusta }\end{array}$ & trichostrongylides (goat) & $\begin{array}{l}5 \times 10^{5} \text { spores } / \mathrm{kg} \mathrm{BW} ; \\
2 \mathrm{~mL} \text { fungal suspension } \\
6 \times 10^{5}\end{array}$ & $\begin{array}{l}47.60-55.93 \% \\
41.96-66.97 \%\end{array}$ & $\begin{array}{l}97.71-99.98 \%, \\
97.99-99.95 \%\end{array}$ & {$[51]$} \\
\hline D. flagrans & cyathostomins (horse) & $\begin{array}{c}\text { chlamydospores } / \mathrm{kg} \\
\text { BW for } 21 \text { days }\end{array}$ & $37.24-98.62 \%$ & & [37] \\
\hline D. flagrans & Haemonchus contortus (sheep) & $\begin{array}{l}5 \times 10^{5} \text { spores } / \mathrm{kg} \mathrm{BW} \\
2 \mathrm{~mL} \text { fungal suspension }\end{array}$ & $55.15-98.82 \%$ & $62.12-99.88 \%$ & {$[43]$} \\
\hline D. flagrans & Strongyloides papillosus (sheep) & $\begin{array}{c}1 \mathrm{~g} \text { Bioverm }{ }^{\circledR} \\
\left(10^{5} \text { chlamydospores } / \mathrm{g}\right)\end{array}$ & & $91.5 \%$ & {$[17,52]$} \\
\hline D. flagrans & $\begin{array}{l}\text { Haemonchus contortus } \\
\text { Trichostrongylus colubriformis, } \\
\text { Teladorsagia circumcincta, } \\
\text { Bunostomum ovina, Chabertia } \\
\text { ovina (sheep) }\end{array}$ & $\begin{array}{c}5 \times 10^{5} \text { spores } / \mathrm{kg} \mathrm{BW}, \\
\text { twice a week }\end{array}$ & $\begin{array}{c}85.4 \%, 87.5 \% \\
90 \%, 81.0 \% \\
71.4 \%\end{array}$ & & [24] \\
\hline D. flagrans & $\begin{array}{c}\text { Haemonchus spp., } \\
\text { Trichostrongylus spp., } \\
\text { Oesophagostomum sp. and } \\
\text { Strongyloides sp. (cattle) }\end{array}$ & $\begin{array}{c}1 \mathrm{~g} \text { Bioverm } \AA / 10 \mathrm{~kg} \mathrm{BW,} \\
\text { (containing } 10^{5} \\
\text { chlamydospores) }\end{array}$ & $88.2 \%$ & & [47] \\
\hline $\begin{array}{c}\text { Mo. } \\
\text { thaumasium }\end{array}$ & cyathostome (horse) & $\begin{array}{c}1 \mathrm{ml} \text { of solution } \\
\text { containing } 1000 \text { spores, } \\
\text { single dose }\end{array}$ & & $95 \%$ & {$[53]$} \\
\hline $\begin{array}{c}\text { Mo. } \\
\text { thaumasium }\end{array}$ & Oxyuris equi (horse) & $\begin{array}{c}\text { Each petri dish } \\
\text { contained fungal isolate }\end{array}$ & & $69 \%$ & {$[54]$} \\
\hline $\begin{array}{l}\text { Mo. } \\
\text { thaumasium }\end{array}$ & $\begin{array}{c}\text { Haemonchus, Trichostrongylus, } \\
\text { Oesophagostomum, and } \\
\text { Strongyloides (sheep) }\end{array}$ & $3 \mathrm{~g}$ of pellets $/ 10 \mathrm{~kg} \mathrm{BW}$ & $79 \%$ & & [55] \\
\hline $\begin{array}{c}\text { Mo. } \\
\text { thaumasium }\end{array}$ & $\begin{array}{c}\text { The gastrointestinal nematodes } \\
\text { (sheep) }\end{array}$ & $\begin{array}{l}100 \mathrm{~g} \text { pellets ( } 20 \mathrm{~g} \text { fungal } \\
\text { mycelia), single dose }\end{array}$ & & $93 \%$ & [27] \\
\hline $\begin{array}{c}\text { Mo. } \\
\text { thaumasium }\end{array}$ & $\begin{array}{c}\text { trichostrongylides, Marshallagia } \\
\text { mongolica (sheep) }\end{array}$ & $\begin{array}{l}5 \times 10^{5} \text { spores } / \mathrm{kg} \mathrm{BW} \\
2 \mathrm{~mL} \text { fungal suspension }\end{array}$ & $51.68-88.16 \%$ & $75.54-99.97 \%$ & [19] \\
\hline
\end{tabular}

Note: trichostrongylides: mainly H. contortus and T. colubriformis; cyathostomins: the gastrointestinal nematodes of horses; BW: body weight; in the dose column, the administered doses for in vivo tests and in vitro tests are separated using semicolons.

\subsubsection{Arthrobotrys}

Arthrobotrys is a typical genus of NF and was the first discovered in the 19th century [56]. This genus is characterized by a high ability to produce conidia and chlamydospores, an innate advantage that is not present in all NF [48]. Arthrobotrys has been deemed one of the most important genera to be used as a potential biocontrol agent among the predatory fungi to date. Conidiophores of species in this genus are typically simple or sparingly branched, bearing apical clusters of conidia $[57,58]$.

Table 2 shows that some species of the genus, including $A$. conoides, $A$. sinense, $A$. musiformis, and $A$. robusta, reduced $80 \%-99 \%$ of GINs in in vitro studies. Although these species of the genus showed high efficiency for trichostrongylides, the percentage reduction of nematodes was different at the same dose. In addition to these species, A. oligospora, $A$. cladodes, and $A$. superba reduced the larvae of Haemonchus sp. by up to $90 \%$. Importantly, 
in in vivo studies, all these species were effective in reducing larvae by approximately $53 \%-97 \%$.

Table 2. In vivo tests and in vitro nematicidal tests of the genera Pochonia, Paecilomyces, and Mucor on gastrointestinal nematodes of domestic animals.

\begin{tabular}{|c|c|c|c|c|}
\hline Fungi & GIN Species & Dose & In Vivo/Vitro Test & Reference \\
\hline Po. chlamydosporia & $\begin{array}{l}\text { Ascaridia galli, Heterakis } \\
\text { spp (chicken) }\end{array}$ & $\begin{array}{c}0.9 \times 10^{6} \text { chlamydospores and } \\
5.4 \times 10^{7} \text { conidia }\end{array}$ & $75 \%$ & [59] \\
\hline Po. chlamydosporia & Oxyuris equi (horse) & $\begin{array}{l}\text { 100g pellets, single does; each Petri } \\
\text { dish contained fungal isolate }\end{array}$ & $21.8 \% / 27.2 \%$ & {$[22,54]$} \\
\hline Po. chlamydosporia & Oxiuris equi (horse) & Fungal isolate added gelatin & $72 \%$ & {$[60]$} \\
\hline Po. chlamydosporia & $\begin{array}{c}\text { Anoplocephala perfoliata } \\
\text { Eggs (horse) }\end{array}$ & $\begin{array}{l}\text { Each Petri dish contained } \\
\text { fungal isolate }\end{array}$ & $71.17 \%$ & [61] \\
\hline Po. chlamydosporia & $\begin{array}{l}\text { Ascaridia galli, } \\
\text { Heterakis gallinarum } \\
\text { (chicken) }\end{array}$ & $\begin{array}{l}3.3 \times 10^{6} \text { conidia/chlamydospores } \\
\text { single dose; subcultures were } \\
\text { inoculated in petri dishes }\end{array}$ & $59.9 \%, 43.2 \%$ & [62] \\
\hline Po. chlamydosporia & Toxocara canis (dog) & $\begin{array}{c}1.0 \times 10^{5} \text { chlamydospores, various } \\
\text { concentrations }\end{array}$ & $78.5 \%$ & [63] \\
\hline Po. chlamydosporia & $\begin{array}{l}\text { Haemonchus, Cooperia, } \\
\text { Oesophagostomum } \\
\text { (bovine) }\end{array}$ & $\begin{array}{l}\text { Each Petri dish contained } \\
\text { fungal isolate }\end{array}$ & $87.4 \%$ & [64] \\
\hline Pa. lilacinus & Oxiuris equi (horse) & Fungal isolate added gelatin & $62 \%$ & {$[60]$} \\
\hline Po. chlamydosporia & Parascaris equorum (horse) & $\begin{array}{l}\text { Each Petri dish contained } \\
\text { fungal isolate }\end{array}$ & $44.9 \%$ & {$[65]$} \\
\hline Pa. lilacinus & Toxocara canis (dog) & $\begin{array}{l}\text { Each Petri dish contained } \\
\text { fungal isolate }\end{array}$ & $20.0 \%$ & {$[66]$} \\
\hline Pa. lilacinus & $\begin{array}{l}\text { Ascaridia galli (chicken) } \\
\text { Toxocara canis (dog) }\end{array}$ & $1.5 \times 10^{5}$ conidia & $\begin{array}{l}15-29 \%, \\
4-28 \%\end{array}$ & [67] \\
\hline Po. Chlamydosporia & $\begin{array}{l}\text { Ascaridia galli (chicken), } \\
\text { Toxocara canis (dog) }\end{array}$ & $1.5 \times 10^{5}$ conidia & $64-86 \%, 26-67 \%$ & [67] \\
\hline Mu. circinelloides & Ascaris suum (pig) & $\begin{array}{l}\text { The mash with fungal spores }(2 \mathrm{~kg} / \\
\text { pig/day); } 1 \times 10^{6} \text { spores }\end{array}$ & $60 / 53 \%$ & [68] \\
\hline Mu. circinelloides & Parascaris equorum (horse) & $1 \mathrm{~mL}$ pellet, $2 \times 10^{6}$ spores $/ \mathrm{mL}$ & $61-67 \%$ & [69] \\
\hline
\end{tabular}

Note: In the dose column, the administered doses for in vivo tests and in vitro tests are separated using semicolons.

Generally, NF can be made into edible pellets, mixed with grass, and then fed into the GT through animal chewing. During this series of processes, chewing causes mechanical damage to NF, and GT physical and chemical factors also have an impact on them [70]. However, in vivo experiments have proven that several species of Arthrobotrys can reach animal feces smoothly through the GT and function successfully.

In contrast to $D$. flagrans, many species of Arthrobotrys have shown effectiveness against trichostrongylides and cyathostomes in various livestock. However, Arthrobotrys is more saprophytic than $D$. flagrans, so it cannot spontaneously form traps without the induction of nematodes, amino acids, or environmental conditions [71].

In short, multiple species in this genus could serve as potential candidates for GIN control.

\subsubsection{Monacrosporium}

Fungi of the Monacrosporium genus have a well-developed ability to produce chlamydospores and form traps on conidia or germlings [30]. The genus is defined by a single conidium produced on each tip of the conidiophores [72].

Importantly, the genus can still survive and maintain nematicidal ability after passing through the GTs of animals, which is a prerequisite for fungi to act on nematodes in feces [73]. Mo. thaumasium has been successfully used in laboratories and under field conditions in the control of GINs in domestic animals (Table 1). Moreover Mo. thaumasium 
acts as a cooperator in combination with other fungi to kill nematodes, and has been shown to improve the efficiency of the predation of nematodes to some extent [74].

As the mycelium of Mo. Thaumasium grows slowly, it needs to be processed before application in experiments. For example, Panagrellus sp. can stimulate the growth of the mycelium of the genus Monacrosporium [53], but this kind of pretreatment is rare. On the other hand, much like D. flagrans, Mo. Thaumasium cannot destroy the eggs of GINs [19]. It is important to discover other fungal species with a strong ability to kill sedentary nematodes (females and eggs).

\subsection{Ovicidal Fungi}

Ovicidal fungi are common soil saprophytes, and are opportunistic isolates obtained from the sedentary stages (female and egg stages) of sedentary nematodes [26,57]. The majority of isolated ovicidal fungi have been found to belong to Humicola, Pochonia, Martiellera, Paecilomyces, and Fusarium [58]. Over the years, Pochonia has been treated as the most representative genus, with significant ovicidal action reported for GINs [26]. Unlike predatory fungi, this group of fungi cannot form trapping devices [75]. Their hyphal penetration and internal egg colonization operates via a mechanical/enzymatic process, with morphological changes in the eggshell and embryo observed [22]. However, the larvicidal activity of ovicidal fungi is rarely evaluated.

\subsubsection{Pochonia}

Pochonia belongs to the Hypocreales order (Ascomycota). In the ovicidal fungal (opportunist) group, Pochonia chlamydosporia (previously known as Verticillium chlamydosporium) stands out [54]. This species is used to form dictyochlamydospores and has been extensively studied as a biocontrol agent [76].

Po. chlamydosporia selectively parasitizes the eggs of gastrointestinal helminths and females. Its appressoria can not only colonize the surfaces of eggs, but also penetrate into the insides of the eggs in the process of fungal action on nematodes [76,77]. To date, Po. chlamydosporia has been used as the most common ovicidal fungi to control GINs in various domestic animals, and it has been shown to reduce nematode eggs by $87.4 \%$ in in vitro tests (Table 2). It is worth mentioning that Pochonia are inoffensive to animals and humans [63].

Although the ovicidal activity of Po. chlamydosporia has been frequently evaluated, it is not known whether it has destructive power against larvae. Vieira et al. specifically studied the ability of Po. chlamydosporia to capture larvae and found that it reduced $66.8 \%$ of L3 GINs in cattle [78], but there are few reports in the literature on the larvicidal activity of this fungus.

\subsubsection{Other}

It has been reported that other genera of NF, including Paecilomyces and Mucor, also have ovicidal action.

Paecilomyces lilacinus is a common hyphomycete which has proven efficiency on the eggs of gastrointestinal parasite nematodes and tapeworms in ruminants and human beings $[79,80]$. It has been found to be able to reduce the number of nematode eggs in the feces of dogs and horses (Table 2), but the effect was not as good as that of Po. chlamydosporia $[60,67]$. The fungus presents a safety risk for humans and animals because it can produce neutral straight-chain peptide toxins (paecilotoxins) [81,82]. As a result, Paecilomyces should be regarded more as a fungicide than as a researched genus.

Mucor circinelloides, a soil filamentous fungus, is able to destroy nematode eggs in the feces of infected animals [83]. In the presence of the eggs of ascarids (Ascaris suum, Toxocara canis, Baylisascaris procyonis), the spores that colonize the animal feces germinate out a mycelium which penetrates the eggshell, invades the interior, and damages both the eggshell and the embryo [84,85]. Furthermore, it can survive in the digestive tracts of animals without loss of biological activity, thus providing a very helpful tool to prevent infection by ascarids among pasturing animals [22]. 
The use of independent predatory and ovicidal fungi is effective for the treatment of GT parasitic nematodes in a variety of domestic animals (including sheep, cattle, goats, horses, pigs, and chickens). For some fungi, such as Po. chlamydosporia and $P a$. lilacinus, although good results have been achieved in vitro, few in vivo studies have been performed due to the lack of a reliable approach for administering a standard dose [86]. Differences in the NF trapping efficiency of nematodes are universal among different species of the same genera and different isolated strains of the same species (Tables 1 and 2). Two factors account for these differences: (1) Internal factors include the cuticular nature of parasitic nematodes and the antigenic variations in the different species of nematodes or different isolates of the same species of fungus [87]. (2) Extrinsic factors include the number of nematodes available and environmental factors, for example, a low density of nematodes being insufficient to stimulate NF to produce trapping structures, resulting in a low predation efficiency of NF [87]. The shaded condition is conducive to the development of fungi and the germination of spores $[14,88,89]$. Thus, NF show variable effects for controling nematodes.

As shown above, the biggest difference between predatory and ovicidal fungi is that the former target larvae while the latter target eggs, cysts, and nematode females [90,91]. When these two types of fungi are used separately, it is inevitable that either the eggs or larvae will escape capture. With the goal of complementing the advantages and promoting the efficiency of hunting nematodes, some researchers have evaluated joint applications, including the combined use of two biological controls or a mix of chemical and biological controls, on GINs in domestic animals (Table 3). To date, the mechanisms of the synergistic interactions among them are not known, but in some cases the strategy seems to have an additive effect.

Table 3. Overview of in vivo and in vitro nematicidal tests of the combined application of representative nematophagous fungi against gastrointestinal nematodes.

\begin{tabular}{|c|c|c|c|}
\hline $\begin{array}{l}\text { Nematophagous Fungus } \\
\text { (\% Reduction of L3 Numbers) }\end{array}$ & GIN Species & Comment & References \\
\hline $\begin{array}{c}\text { A. cladodes }(77.0 \%)+\text { Po. chlamydosporia }(66.8 \%) \\
{[86.3 \%]}\end{array}$ & $\begin{array}{c}\text { Haemonchus, Cooperia, } \\
\text { Oesophagostomum. (cattle) } \\
\text { Haemonchus sp., }\end{array}$ & In vitro, synergistic effect & [78] \\
\hline $\begin{array}{c}\text { D. flagrans }(58.9 \%)+\text { Mo. thaumasium }(34 \%) \\
{[83 \%]}\end{array}$ & $\begin{array}{l}\text { Trichostrongylus spp., } \\
\text { Strongyloides sp., } \\
\text { Oesophagostomum sp. (sheep) }\end{array}$ & In vitro, synergistic effect & {$[92,93]$} \\
\hline $\begin{array}{c}\text { A. cladodes }(81.73 \%)+\text { Po. chlmydosporia } \\
(68.25 \%)[92.67 \%]\end{array}$ & $\begin{array}{l}\text { Haemonchus, Cooperia, } \\
\text { Oesophagostomum (cattle) }\end{array}$ & $\begin{array}{l}\text { In vitro, synergistic effect, } \\
\text { compatibility }\end{array}$ & [21] \\
\hline $\begin{array}{c}\text { D. flagrans }(61.6 \%)+\text { Mo. thaumasium }(66.1 \%) \\
{[92.4 \%] ; \text { D. flagrans }(61.6 \%)+\text { Po. chlamydosporia }} \\
(73.2 \%)[86.8 \%] ; \text { Mo. thaumasium }(66.1 \%)+\text { Po. } \\
\text { chlamydosporia }(73.2 \%)[77.3 \%]\end{array}$ & cyathostomin (horse) & $\begin{array}{c}\text { In vitro, synergistic effect, } \\
\text { compatibility (D. flagrans }+ \\
\text { Mo. thaumasium) }\end{array}$ & {$[69,94]$} \\
\hline $\begin{array}{c}\text { D. flagrans }(96.4 \%)+\text { Mo. thaumasium }(93.4 \%) \\
{[90.7 \%] ; \text { D. flagrans }(96.4 \%)+\text { A. robusta }[86.3 \%]} \\
\text { D. flagran }(96.4 \%)+\text { Mo. thaumasium }+A . \\
\text { robusta }[78.3 \%]\end{array}$ & $\begin{array}{l}\text { Cooperia sp., Haemonchus, } \\
\text { Oesophagostomum (cattle) }\end{array}$ & $\begin{array}{c}\text { In vitro, antagonistic effect, } \\
\text { incompatibility }(D \text {. flagrans }+ \\
\text { A. robusta) }\end{array}$ & [41] \\
\hline $\begin{array}{c}\text { D. flagrans }(91.5 \%)+\text { Clonostachys rosea }(88.9 \%) \\
{[74.5 \%]}\end{array}$ & Haemonchus contortus (sheep) & In vitro, antagonistic effect & {$[95,96]$} \\
\hline $\begin{array}{c}\text { A. robusta }+ \text { D. flagrans }[93 \%] \\
\text { A. conoides }+ \text { Mo. thaumasium }[98 \%]\end{array}$ & $\begin{array}{l}\text { The gastrointestinal } \\
\text { nematodes (goat) }\end{array}$ & $\begin{array}{l}\text { In vitro, associated } \\
\text { application showed high } \\
\text { predatory activity }\end{array}$ & [97] \\
\hline $\begin{array}{c}\text { D. flagrans }+ \text { Po. chlamydosporia }+ \text { A. robusta } \\
{[94 \%, 91.8 \%]}\end{array}$ & $\begin{array}{c}\text { Haemonchus sp., Cooperia sp., } \\
\text { Oesophagos- } \\
\text { tomum sp. (cattle) }\end{array}$ & $\begin{array}{l}\text { In vitro and vivo, associated } \\
\text { application showed high } \\
\text { predatory activity } \\
\text { In vitro associated }\end{array}$ & [98] \\
\hline D. flagrans + Mo. thaumasium $(>80 \%)$ & cyathostomin (horse) & $\begin{array}{l}\text { application showed high } \\
\text { predatory activity }\end{array}$ & [99] \\
\hline
\end{tabular}




\section{Potential New Strategies of Biological Control}

The use of a combination of biological controls or mixed biological and chemical controls may reduce the flaws evident in individual administration, and it may even enhance fungal predation ability [41]. However, there are compatibilities or incompatibilities (the combined agents can produce compounds that inhibit each other in a joint application) among some fungi, predators and compounds, and an incompatibility can seriously prevent the combined strategy from controlling nematodes [21,100,101].

\subsection{Coadministration of Fungi with Fungi}

According to the current studies, the methods of associated application among fungi can be summarized into three forms: a combination of two or three fungi, a combination of different groups of fungi (predatory and ovicidal), and a combination of identical groups of fungi (predatory fungi) (Table 3). In combined administration, these fungi are required to meet two basic requirements: first, they are required to have the ability to pass through the animal's GT without losing vitality, as if they were administered alone; second, they must not inhibit each other's growth [100]. These are two basic prerequisites to realize additive effects. To date, the selected fungi are considered effective species that have previously been proven to be able to prey on nematodes when used alone, so they generally satisfy the first prerequisite, while the second needs to be reassessed.

The associations between identical groups of fungi (D. flagrans + Mo. thaumasium $)$ or different groups of fungi (A. cladode + Po. chlmydosporia, D. flagrans + Po. chlamydosporia, Mo. thaumasium + Po. chlamydosporia) have been shown to have synergistic effects, which significantly enhance predation efficiency compared to using a single fungus alone $[21,78,92,93]$. However, not all combined applications have been tested for the compatibility between the fungal participants in the joint action; only $D$. flagrans $+M o$. Thaumasium and A. cladode $+P$. chlmydosporia have presented growth compatibility $[21,69,94]$. In contrast, some joint strategies have shown antagonistic effects. Luns et al. noted that the pairwise combination of $D$. flagrans with Mo. thaumasium or A. robusta showed a lower nematicidal percentage than $D$. flagrans alone, and that the combination of all three fungi was the least effective [41]. Similarly, the combination which includes Clonostachys rosea has been found to be less efficient than D. flagrans alone $[95,96]$. For $D$. flagrans and $A$. robusta, the low predation efficiency was due to the incompatibility of the two fungi [41]. In addition, although some studies have reported that joint application was effective, these strategies have not been proven to have additive effects [97-99]. Therefore, the usefulness of these strategies needs to be examined closely if their predation efficiency cannot exceed the effect of a single-fungus treatment.

It seems as if a combination of different groups of fungi may be more effective than a combination of the same group of fungi, based on the differences in the predation targets of predatory and ovicidal fungi, but this is only a guess. It stands to reason that comparisons between combined applications are restricted because (1) different experimental methods or materials (strains and nematode species) and different test targets (the reduction of L3 in feces, the mean number of eggs per gram of feces (EPG) or the number of infective larvae $/ \mathrm{kg}$ of dry matter (L3/ kg D.M.), etc.) are generally used [74,99], and (2) the convincing cases are rare; when these variables are identical, the results of individual cases are contrary to the hypotheses, e.g., D. flagrans + Mo. Thaumasium being more effective than $D$. flagrans + Po . Chlamydosporia [94]. Therefore, based on the results of the current study, it is impossible to know which fungal combination form works better. Nevertheless, it is absolutely necessary to consider whether there is compatibility between the collaborators before choosing strains. This compatibility can be verified by determining whether zones of inhibition appear in a co-culture of fungi on the same plate [90].

\subsection{Coadministration of Fungi with Compounds}

The combination of chemical controls and NF involves chemical anthelmintic drugs and organic compounds, and the combination of these two kinds of compounds with NF 
has different effects. Among them, the combination between chemical drugs and NF seems to be effective, because the former acts on nematodes in animals, whereas the latter acts on free-living nematodes in pasture $[19,102]$. From the perspective of the predation target, this combination could disrupt the whole life cycle of nematodes, but there have been relatively few successful cases of doing so. However, organic compounds could act as efficient vehicles in the topical administration of NF [103,104].

Reports of synergistic effects for the simultaneous administration of chemical drugs and NF are scarce. Vilela et al. reported that the combination of $D$. flagrans and levamisole hydrochloride was feasible, with a significantly lower EPG recorded for their combination than for exclusive administration of the chemical drug [105]. In this regard, Wang et al. similarly noted that $D$. flagrans had strong tolerance to levamisole hydrochloride [106]. Nevertheless, most studies suggest an antagonistic effect between chemical drugs and NF. For example, the antiparasitic compounds albendazole, ivermectin, and levamisole have been found to have a negative impact on the viability of $A$. oligospora, Pa. lilacinus $D$. flagrans, and Arthrobotrys sp. [107]. D. flagrans has been found to have high susceptibility to tested drugs, including fenbendazole, thiabendazole and ivermectin, carbendazim, and difenoconazole [106]. In vivo tests also confirmed that chemical drugs inhibited the activity of $D$. flagrans spores when used in combination with albendazole [108].

On the other hand, numerous studies have incorporated fungi into a sodium alginate matrix and produced edible pellets, which helps fungi overcome undesirable factors to successfully pass through animal GTs and contributes to the long-term preservation of spores $[27,99,103]$. Dimethyl sulfoxide as a permeabilizer and mineral oil as an adjuvant assisted in an excellent penetration and adhesion of conidia to the nematode epidermis [109,110]. Importantly, this method presented a high affinity for conidia fungi and effectively acted on Rhabditis spp. [104]. These findings were all confirmed under laboratory conditions, except for the compatibility of fungi, which was confirmed with an antiparasitic in vivo test $[108,111]$.

The above results indicate that not all chemical compounds interfere with fungal activity, making their future combined use possible.

\section{Concluding Remarks}

The independent use of a representative species of NF has achieved satisfactory results in controlling GINs, which has stimulated human interest in discovering novel candidates for nematode-trapping fungi. According to the latest assessment, fungal species richness has reached 12 million globally [112], but only approximately $1.2 \%(140,000)$ species have been described [113]. However, there are only around 200 species of nematode-trapping fungi with the ability to prey on free-living stage nematodes, accounting for one thousandth of the known fungal population [114]; the number of fungal species that remain to be described leaves great potential for the discovery of novel NF. Furthermore, the ability to capture GINs is different for different species of NF. D. flagrans and A. robusta, for example, have a significant difference in their ability to reduce the number of GINs; Oliveira et al. believe that it is essential to test the nematicidal ability of each species separately [48]. From the perspective of predatory characteristics, in vivo and in vitro tests need to be continuously performed to verify the efficacy of specific nematophagous fungal species for GIN treatment. Moreover, environmental factors (temperature, humidity, and altitude) have an impact on NF capture of GINs, since each species has its own environmental adaptation ability [48]. Thus, some scholars have suggested isolating potential candidates from the isolates of NF which root in animal feces on local pastures [50,51]. This method makes it easier to obtain potential candidate strains adapted to local climatic conditions, and would reduce invasion by alien species.

Related cases of associated applications have shown that this new method is promising in GIN control, and it has certain practical and research value in the future. Differences in predation efficiency for identical groups of NF, and the different mechanisms of the different groups of NF, may contribute to the positive effects of combinations of fungi. 
Although resistance is quickly developed to chemical drugs, they are more effective at killing nematodes than fungi, so the combination of the two could also reduce resistance and enhance nematicidal efficiency. Further studies are still needed to establish the pattern of combining NF with chemical drugs, such as the compatibility, appropriate dose, and time $[104,106]$.

Author Contributions: Conceptualization, Y.Z.; methodology, S.L., D.W. and J.G.; software, S.L., D.W. and J.G.; validation, Y.Z. and S.L.; formal analysis, S.L., D.W. and J.G.; investigation, S.L., D.W. and J.G.; resources, S.L.; data curation, Y.Z. and S.L.; writing-original draft preparation, Y.Z. and S.L.; writing-review and editing, Y.Z.; visualization, Y.Z.; supervision, Y.Z.; project administration, Y.Z.; funding acquisition, Y.Z. All authors have read and agreed to the published version of the manuscript.

Funding: This research was jointly funded by the National Natural Science Foundation of China (31760010) to Y.Z., and Department of Science and Technology of Yunnan Province (202101AT070184) to Y.Z.

Institutional Review Board Statement: Not applicable.

Informed Consent Statement: Not applicable.

Data Availability Statement: Not applicable.

Acknowledgments: We thank Jackson V. Araújo for the invitation.

Conflicts of Interest: The authors declare no conflict of interest.

\section{References}

1. Hoogen, J.; Geisen, S.; Routh, D.; Ferris, H.; Crowther, T.W. Soil nematode abundance and functional group composition at a global scale. Nature 2019, 572, 194-198. [CrossRef] [PubMed]

2. Geisen, S.; Snoek, L.B.; Hooven, F.T.; Duyts, H.; Kostenko, O.; Bloem, J.; Martens, H.; Quist, C.W.; Helder, J.A.; van der Putten, W.H. Integrating quantitative morphological and qualitative molecular methods to analyse soil nematode community responses to plant range expansion. Methods Ecol. Evol. 2018, 9, 1366-1378. [CrossRef]

3. Bongers, T.; Bongers, M. Functional diversity of nematodes. Appl. Soil Ecol. 1998, 10, 239-251. [CrossRef]

4. Yeates, G.W.; Bongers, T.; de Goede, R.G.M.; Freckman, D.W.; Georgieva, S.S. Feeding habits in soil nematode families and genera-an outline for soil ecologists. J. Nematol. 1993, 25, 315-331. [CrossRef]

5. Yadav, C.L.; Uppal, R.P.; Kalra, S. An outbreak of haemonchosis associated with anthelmintic resistance in sheep. Int. J. Parasitol. 1993, 23, 411-413. [CrossRef]

6. Charlier, J.; Mariska, V.; Kenyon, F.; Skuce, P.; Vercruysse, J. Chasing helminths and their economic impact on farmed ruminants. Trends Parasitol. 2014, 30, 361-367. [CrossRef]

7. Grisi, L.; Leite, R.C.; Martins, J.; Barros, A.; Andreotti, R.; CancAdo, P.; León, A.; Pereira, J.B.; Villela, H.S. Reassessment of the potential economic impact of cattle parasites in Brazil. Rev. Bras. Parasitol. Vet. 2014, 23, 150-156. [CrossRef]

8. Roeber, F.; Jex, A.R.; Gasser, R.B. Impact of gastrointestinal parasitic nematodes of sheep, and the role of advanced molecular tools for exploring epidemiology and drug resistance-an Australian perspective. Parasites Vectors 2013, 6, 153. [CrossRef]

9. Bolajoko, M.B.; Rose, H.; Musella, V.; Bosco, A.; Rinaldi, L.; Dijk, J.V.; Cringoli, G.; Morgan, E.R. The basic reproduction quotient $\left(\mathrm{Q}_{0}\right)$ as a potential spatial predictor of the seasonality of ovine haemonchosis. Geospat. Health 2015, 9, 333-350. [CrossRef]

10. Rodriguez-Martinez, R.; Mendoza-de-Gives, P.; Aguilar-Marcelino, L.; Lopez-Arellano, M.E.; Gamboa-Angulo, M.; RosasSaito, G.H.; Reyes-Estebanez, M.; Garcia-Rubio, V.G. In vitro lethal activity of the nematophagous fungus Clonostachys rosea (Ascomycota: Hypocreales) against nematodes of five different taxa. BioMed Res. Int. 2018, 2018, 3501827. [CrossRef]

11. Olsen, O.W. Animal parasites: Their life cycles and ecology. J. Parasitol. 1974, 60, 924.

12. Kenyon, F.; Greer, A.W.; Coles, G.C.; Cringoli, G.; Papadopoulos, E.; Cabaret, J.; Berrag, B.; Varady, M.; Van Wyk, J.A.; Thomas, E.; et al. The role of targeted selective treatments in the development of refugia-based approaches to the control of gastrointestinal nematodes of small ruminants. Vet. Parasitol. 2009, 164, 3-11. [CrossRef] [PubMed]

13. Sagüés, M.; Purslow, P.; Fernández, S.; Fusé, L.; Iglesias, L.; Saumell, C. Nematophagous fungi used for the biological control of gastrointestinal nematodes in livestock and administration routes. Rev. Iberoma. Micol. 2011, 28, 143-147. [CrossRef] [PubMed]

14. Franco, B.; Alberto, F.L.; Federica, S.M.; Emilia, I.L.; Silvina, F.A.; Sara, Z.; Inés, G.; Alfredo, S.C. Predatory effect of Duddingtonia flagrans on infective larvae of gastro-intestinal parasites under sunny and shaded conditions. Exp. Parasitol. 2018, 193, 27-32. [CrossRef]

15. Silveira, W.; Braga, F.R.; Alexandre, D.; Santos, L.D.; Domingues, R.R.; Aguiar, A.R.; Ferraz, C.M.; Carvalho, L.D.; Thiago, D.; Zanuncio, J.C. Nematophagous fungi combinations reduce free-living stages of sheep gastrointestinal nematodes in the field. $J$. Invertebr. Pathol. 2017, 150, 1-5. [CrossRef] 
16. Tariq, K.A. A review of the epidemiology and control of gastrointestinal nematode infections of small ruminants. Proc. Natl. Acad. Sci. India A 2015, 85, 693-703. [CrossRef]

17. Braga, F.R.; Ferraz, C.M.; Silva, E.; Araújo, J. Efficiency of the Bioverm (Duddingtonia flagrans) fungal formulation to control in vivo and in vitro of Haemonchus contortus and Strongyloides papillosus in sheep. 3 Biotech 2020, 10, 62. [CrossRef]

18. Xue, Y.J.; Li, E.L.; Wang, A.H.; Cai, K.Z. Predatory activity and passage of six nematophagous fungi species in gastrointestinal tract of trichostrongylide-infected sheep. Biocontrol Sci. Technol. 2018, 28, 654-662. [CrossRef]

19. Dai, H.W.; Xu, Q.; Wang, B.B.; Jia, X.Y.; Wan, X.M.; Yang, X.C.; Cai, K.Z.; Liu, Z.B. In vitro, in vivo and interaction studies of nematophagous fungus Arthrobotrys thaumasia (Monacrsporium thaumasium) with the larave of trichostrongylides of sheep. J. Parasitol. 2017, 103, 692-698. [CrossRef]

20. Ocampo-Gutierrez, A.Y.; Hernandez-Velazquez, V.M.; Aguilar-Marcelino, L.; Cardoso-Taketa, A.; Zamilpa, A.; Lopez-Arellano, M.E.; Gonzalez-Cortazar, M.; Hernandez-Romano, J.; Reyes-Estebanez, M.; Mendoza-De Gives, P. Morphological and molecular characterization, predatory behaviour and effect of organic extracts of four nematophagous fungi from Mexico. Fungal Ecol. 2021, 49, 101004. [CrossRef]

21. Vieira, T.S.; Oliveira, I.; Campos, A.K.; Araújo, J. Association and predatory capacity of fungi Pochonia chlamydosporia and Arthrobotrys cladodes in the biological control of parasitic helminths of bovines. Parasitology 2019, 146, 1347-1351. [CrossRef] [PubMed]

22. Braga, F.R.; Araujo, J.V.; Silva, A.R.; Carvalho, R.O.; Araujo, J.M.; Ferreira, S.R.; Carvalho, G.R. Viability of the nematophagous fungus Pochonia chlamydosporia after passage through the gastrointestinal tract of horses. Vet. Parasitol. 2010, 168, 264-268. [CrossRef] [PubMed]

23. Sagüés, M.; Fusé, L.; Fernández, A.; Iglesias, L.E.; Moreno, F.C.; Saumell, C.A. Efficacy of an energy block containing Duddingtonia flagrans in the control of gastrointestinal nematodes of sheep. Parasitol. Res. 2011, 109, 707-713. [CrossRef] [PubMed]

24. Liu, X.Y.; Chang, F.F.; Zhao, T.Y.; Huang, H.Y.; Li, F.D.; Wang, F.; Wang, B.B.; Wang, F.H.; Liu, Q.; Luo, Q.H.; et al. Biological control of sheep gastrointestinal nematode in three feeding systems in Northern China by using powder drug with nematophagous fungi. Biocontrol Sci. Technol. 2020, 30, 701-715. [CrossRef]

25. Yang, J.; Liang, L.; Li, J. Nematicidal enzymes from microorganisms and their applications. Appl. Microbiol. Biotechnol. 2013, 97, 7081-7095. [CrossRef]

26. Braga, F.R.; Araújo, J. Nematophagous fungi for biological control of gastrointestinal nematodes in domestic animals. Appl. Microbiol. Biotechnol. 2014, 98, 71-82. [CrossRef]

27. Da Costa, P.W.L.; Alvares, F.B.V.; Bezerra, R.A.; Sarmento, W.F.; da Silva, F.F.; Rodrigues, J.A.; Feitosa, T.F.; de Araujo, J.V.; Braga, F.R.; Vilela, V.L.R. Effect of refrigeration storage of nemathophagous fungi embedded in sodium alginate pellets on predatory activity against asinine gastrointestinal nematodes. Biocontrol Sci. Technol. 2019, 29, 1106-1117. [CrossRef]

28. Zhang, Y.; Li, S.S.; Li, H.X.; Wang, R.R.; Zhang, K.Q.; Xu, J.P. Fungi-Nematode interactions: Diversity, ecology, and biocontrol prospects in agriculture. J. Fungi 2020, 6, 206. [CrossRef]

29. Liu, X.; Xiang, M.; Che, Y. The living strategy of nematophagous fungi. Mycoscience 2009, 50, 20-25. [CrossRef]

30. Saxena, G.; Mittal, N. Trap formation by conidia of nematode-trapping Monacrosporium spp. Mycol. Res. 1995, 99, 839-840. [CrossRef]

31. Saxena, G. Biological control of root-knot and cyst nematodes using nematophagous fungi. In Root Biology; Springer: Berlin/Heidelberg, Germany, 2018. [CrossRef]

32. Elias, D.; Leite, S.B.; Humberto, D. Nematophagous fungi: Far beyond the endoparasite, predator and ovicidal groups. Agric. Nat. Resour. 2018, 52, 1-8. [CrossRef]

33. Lysek, H. Classification of ovicide fungi according to type of ovicidity. Acta Univ. Palacki Olomuc Fac. Med. 1976, 76, 9-13.

34. Araújo, J.M.; Araújo, J.V.; Braga, F.R.; Carvalho, R.O.; Campos, A.K. Interaction and ovicidal activity of nematophagous fungus Pochonia chlamydosporia on Taenia saginata eggs. Exp. Parasitol. 2009, 121, 338-341. [CrossRef] [PubMed]

35. Rubner, A. Revision of predacious hyphomycetes in the Dactylella-Monacrosporium complex. Stud. Mycol. 1996, $39,1-129$.

36. Kendrick, B. Ainsworth \& Bisby's dictionary of the fungi-A review. Mycologist 2003, 17, 17-19. [CrossRef]

37. Buzatti, A.; De Paula Santos, C.; Fernandes, M.A.M.; Yoshitani, U.Y.; Sprenger, L.K.; dos Santos, C.D.; Molento, M.B. Duddingtonia flagrans in the control of gastrointestinal nematodes of horses. Exp. Parasitol. 2015, 159, 1-4. [CrossRef]

38. Gronvold, J.; Henriksen, S.A.; Larsen, M.; Nansen, P.; Wolstrup, J. Biological control-Aspects of biological control-With special reference to arthropods, protozoans and helminths of domesticated animals. Vet. Parasitol. 1996, 64, 47-64. [CrossRef]

39. Silva, M.; Braga, F.R.; Borges, L.A.; Oliveira, P.D.; Lima, W.; Araujo, J. Producción de conidios y clamidosporas de los hongos Duddingtonia flagrans y Monacrosporium thaumasium en diferentes medios sólidos. Arq. Do Inst. Biol. 2015, 82, 00218. [CrossRef]

40. Sanyal, P.K.; Sarkar, A.K.; Patel, N.K.; Mandal, S.C.; Pal, S. Formulation of a strategy for the application of Duddingtonia flagrans to control caprine parasitic gastroenteritis. J. Helminthol. 2008, 82, 169-174. [CrossRef]

41. Luns, F.D.; Assis, R.C.L.; Silva, L.P.C.; Ferraz, C.M.; Braga, F.R.; de Araujo, J.V. Coadministration of nematophagous fungi for biological control over nematodes in Bovine in the south-eastern Brazil. BioMed Res. Int. 2018, 2018, 2934674. [CrossRef]

42. Assis, R.C.L.; Luns, F.D.; Araujo, J.V.; Braga, F.R.; Assis, R.L.; Marcelino, J.L.; Freitas, P.C.; Andrade, M.A.S. Comparison between the action of nematode predatory fungi Duddingtonia flagrans and Monacrosporium thaumasium in the biological control of bovine gastrointestinal nematodiasis in tropical southeastern Brazil. Vet. Parasitol. 2013, 193, 134-140. [CrossRef] [PubMed] 
43. Wang, B.B.; Wang, F.H.; Qiang, X.; Wang, K.Y.; Cao, X. In vitro and in vivo studies of the native isolates of nematophagous fungi from China against the larvae of trichostrongylides. J. Basic Microbiol. 2017, 57, 265-275. [CrossRef] [PubMed]

44. Zhang, W.; Liu, D.; Yu, Z.; Hou, B.; Wang, R. Comparative genome and transcriptome analysis of the nematode-trapping fungus Duddingtonia flagrans reveals high pathogenicity during nematode infection. Biol. Control. 2020, 143, 104159. [CrossRef]

45. Park, J.; Lee, S.; Choi, J.; Ahn, K.; Park, B.; Park, J.; Kang, S.; Lee, Y.H. Fungal cytochrome P450 database. BMC Genom. 2008, 9, 402. [CrossRef]

46. Barron, G.L. Predatory fungi, wood decay, and the carbon cycle. Biodiversity 2003, 4, 3-9. [CrossRef]

47. Rodrigues, J.A.; Roque, F.L.; Alvares, F.B.V.; da Silva, A.L.P.; de Lima, E.F.; Filho, G.M.D.; Feitosa, T.F.; de Araujo, J.V.; Braga, F.R.; Vilela, V.L.R. Efficacy of a commercial fungal formulation containing Duddingtonia flagrans (Bioverm (R)) for controlling bovine gastrointestinal nematodes. Rev. Bras. Parasitol. Vet. 2021, 30, e026620. [CrossRef] [PubMed]

48. Isabela, D.; Vieira, I.; Carvalho, L.D.; Campos, A.K.; Freitas, S.G.; Araujo, J.D.; Braga, F.R.; Araújo, J.D. Reduction of bovine strongilides in naturally contaminated pastures in the southeast region of Brazil. Exp. Parasitol. 2018, 194, 9-15. [CrossRef]

49. Oliveira, I.D.; de Carvalho, L.M.; Vieira, I.S.; Campos, A.K.; Freitas, S.G.; de Araujo, J.M.; Braga, F.R.; de Araujo, J.V. Using the fungus Arthrobotrys cladodes var. macroides as a sustainable strategy to reduce numbers of infective larvae of bovine gastrointestinal parasitic nematodes. J. Invertebr. Pathol. 2018, 158, 46-51. [CrossRef]

50. Cai, K.Z.; Wang, F.H.; Wang, B.B.; Liu, J.L.; Wang, K.Y.; Xu, Q.; Xue, Y.J.; Wang, F.; Zhang, C.; Fang, W.X.; et al. In vitro predatory activity of Arthrobotrys oligospora and after passing through gastrointestinal tract of small ruminants on infective larvae of trichostrongylides. Exp. Parasitol. 2017, 177, 104-111. [CrossRef]

51. Cai, K.Z.; Wang, B.B.; Xu, Q.; Liu, J.L.; Wang, K.Y.; Xue, Y.J.; Zhang, H.Y.; Wang, H.Y.; Cao, X.; Ma, Z.R. In vitro and in vivo studies of nematophagous fungi Arthrobotrys musiformis and Arthrobotrys robusta against the larvae of the trichostrongylides. Acta Parasitol. 2017, 62, 666-674. [CrossRef]

52. De Oliveira, L.; Dias, F.G.S.; Melo, A.L.T.; de Carvalho, L.M.; Silva, E.N.; de Araujo, J.V.D. Bioverm(R) in the control of nematodes in beef cattle raised in the central-west region of Brazil. Pathogens 2021, 10, 548. [CrossRef] [PubMed]

53. Castro, A.A.; Oliveira, C.R.C.; Anjos, D.H.S.; Ornellas, E.I.; Rodrigues, M.L.A. Potencial dos fungos nematofagos Arthrobotrys sp. e Monacrosporium thaumasium para o controle de larvas de ciatostomineos de equinos (Nematoda: Cyathostominae). Rev. Bras. Parasitol. Vet. 2003, 12, 53-57.

54. Braga, F.R.; Araujo, J.V.; Silva, A.R.; Araujo, J.M.; Carvalho, R.O.; Campos, A.K.; Tavela, A.O.; Ferreira, S.R.; Frassy, L.N.; Alves, C.D.F. Duddingtonia flagrans, Monacrosporium thaumasium and Pochonia chlamydosporia as possible biological control agents of Oxyuris equi and Austroxyuris finlaysoni. J. Helminthol. 2010, 84, 21-25. [CrossRef] [PubMed]

55. Silva, F.F.; Costa, P.W.L.; Bezerra, R.A.; Silva, S.S.; Vilela, V.L.R. Influnce of storage time of Monacrosporium thaumasium pellets on the predation of infective larvae of sheep gastrointestinal nematodes. Ars Vet. 2018, 34, 115-119. [CrossRef]

56. Cooke, R.C.; Godfrey, B. A key to the nematode-destroying fungi. Trans. Br. Mycol. Soc. 1964, 47, 61-74. [CrossRef]

57. Barron, G.L. Nematophagous fungi-New Arthrobotrys with non-septate conidia. Can. J. Bot. 1979, 57, 1371-1373. [CrossRef]

58. Blaszkowska, J.; Kurnatowski, P.; Wojcik, A.; Goralska, K.; Szwabe, K. In vitro evaluation of the ovistatic and ovicidal effect of the cosmopolitan filamentous fungi isolated from soil on Ascaris suum eggs. Vet. Parasitol. 2014, 199, 165-171. [CrossRef]

59. Thapa, S.; Mejer, H.; Thamsborg, S.M.; Lekfeldt, J.D.S.; Wang, R.; Jensen, B.; Magid, J.; Meyling, N.V. Survival of chicken ascarid eggs exposed to different soil types and fungi. Appl. Soil Ecol. 2017, 121, 143-151. [CrossRef]

60. Braga, F.R.; Araujo, J.V.; Soares, F.E.F.; Tavela, A.O.; Araujo, J.M.; Carvalho, R.O.; Fernandes, F.M.; Queiroz, J.H. Enzymatic analysis and in vitro ovicidal effect of Pochonia chlamydosporia and Paecilomyces lilacinus on Oxyuris equi eggs of horses. Biocontrol Sci. Technol. 2012, 22, 685-696. [CrossRef]

61. Silva, A.R.; Araújo, J.; Braga, F.R.; Alves, C.; Filho, J. Destruction of Anoplocephala perfoliata eggs by the Nematophagous fungus Pochonia chlamydosporia. J. Equine Vet. Sci. 2010, 30, 701-704. [CrossRef]

62. Valado, M.C.; Carvalho, L.; Vieira, T.S.; Neves, P.H.; Araújo, J. Germination capacity of the Pochonia chlamydosporia fungus after its passage through the gastrointestinal tract of domestic chickens (Gallus gallus domesticus). Exp. Parasitol. 2020, $216,107936$. [CrossRef] [PubMed]

63. Araujo, J.M.; Araújo, J.; Braga, F.R.; Ferreira, S.R.; Tavela, A. Predatory activity of chlamydospores of the fungus Pochonia chlamydosporia on Toxocara canis eggs under laboratory conditions. Rev. Bras. Parasitol. Vet. 2013, 22, 171-174. [CrossRef] [PubMed]

64. Vieira, I.S.; Oliveira, I.D.; Campos, A.K.; de Araujo, J.V. In vitro biological control of bovine parasitic nematodes by Arthrobotrys cladodes, Duddingtonia flagrans and Pochonia chlamydosporiaunder different temperature conditions. J. Helminthol. 2020, 94, e194. [CrossRef] [PubMed]

65. Carvalho, L.D.; Braga, F.R.; Domingues, R.R.; Araujo, J.M.; Lelis, R.T.; Paula, A.D.; Silveira, W.; Araújo, J.D. Interaction of the nematophagous fungus Pochonia chlamydosporia and Parascaris equorum eggs in different culture media. J. Basic Microbiol. 2014, 54, S109-S114. [CrossRef] [PubMed]

66. Carvalho, R.O.; Araújo, J.; Braga, F.R.; Araujo, J.M.; Alves, C. Ovicidal activity of Pochonia chlamydosporia and Paecilomyces lilacinus on Toxocara canis eggs. Vet. Parasitol. 2010, 169, 123-127. [CrossRef] [PubMed]

67. Thapa, S.; Meyling, N.V.; Katakam, K.K.; Thamsborg, S.M.; Mejer, H. A method to evaluate relative ovicidal effects of soil microfungi on thick-shelled eggs of animal-parasitic nematodes. Biocontrol Sci. Technol. 2015, 25, 756-767. [CrossRef] 
68. Cortiñas, F.J.; Cazapal-Monteiro, C.F.; Hernández, J.A.; Arroyo, F.L.; Miguélez, S.; Suárez, J.; López de Arellano, M.E.; SánchezAndrade, R.; Mendoza de Gives, P.; Paz-Silva, A.; et al. Potential use of Mucor circinelloides for the biological control of certain helminths affecting livestock reared in a care farm. Biocontrol Sci. Technol. 2015, 25, 1443-1452. [CrossRef]

69. Arroyo, F.L.; Arias, M.S.; Cazapal-Monteiro, C.F.; Hernández, J.A.; Suárez, J.; Miguélez, S.; Romasanta, A.; Sánchez-Andrade, R.; Paz-Silva, A. The capability of the fungus Mucor circinelloides to maintain parasiticidal activity after the industrial feed pelleting enhances the possibilities of biological control of livestock parasites. Biol. Control 2016, 92, 38-44. [CrossRef]

70. Cespedes-Gutierrez, E.; Aragon-Novoa, D.M.; Gomez-Alvarez, M.I.; Cortes-Rojas, D.F. In vitro evaluation of physicochemical variables on the nematophagous fungus Duddingtonia flagrans. J. Basic Microbiol. 2021, 61, 547-556. [CrossRef]

71. Liu, K.K.; Zhang, W.W.; Lai, Y.L.; Xiang, M.C.; Wang, X.N.; Zhang, X.Y.; Liu, X.Z. Drechslerella stenobrocha genome illustrates the mechanism of constricting rings and the origin of nematode predation in fungi. BMC Genom. 2014, 15, 114. [CrossRef]

72. Subramanian, C.V. Dactylella, Monacrosporium and Dactylina. J. Indian Bot. Soc. 1963, 42, 291-300.

73. Melo, L.M.; Bevilaqua, C.M.L.; Araújo, J.V.D.; Melo, A.C.F.L. Atividade predatória do fungo Monacrosporium thaumasium contra o nematóide Haemonchus contortus, após passagem pelo trato gastrintestinal de caprinos. Cienc. Rural 2003, 33, 169-171. [CrossRef]

74. Vinícius, L.; Feitosa, T.F.; Braga, F.R.; Araújo, J.D.; Santos, A.D.; Morais, D.D.; Vagner, D.; Athayde, A. Coadministration of nematophagous fungi for biological control over gastrointestinal helminths in sheep in the semiarid region of northeastern Brazil. Vet. Parasitol. 2016, 221, 139-143. [CrossRef]

75. Niu, X.M.; Zhang, K.Q. Arthrobotrys oligospora: A model organism for understanding the interaction between fungi and nematodes. Mycology 2011, 2, 59-78. [CrossRef]

76. Braga, F.R.; Araújo, J.; Campos, A.K.; Silva, A.R.; Araujo, J.M.; Carvalho, R.O.; Corrêa, D.; Pereira, C. In vitro evaluation of the effect of the nematophagous fungi Duddingtonia flagrans, Monacrosporium sinense and Pochonia chlamydosporia on Schistosoma mansoni eggs. World J. Microbiol. Biotechnol. 2008, 24, 2713-2716. [CrossRef]

77. Lopez-Llorca, L.V.; Olivares-Bernabeu, C.; Salinas, J.; Jansson, H.B.; Kolattukudy, P.E. Pre-penetration events in fungal parasitism of nematode eggs. Mycol. Res. 2002, 106, 499-506. [CrossRef]

78. Vieira, T.S.; Oliveira, I.; Campos, A.K.; Araújo, J. Arthrobotrys cladodes and Pochonia chlamydosporia: Nematicidal effects of single and combined use after passage through cattle gastrointestinal tract. Exp. Parasitol. 2020, 218, 108005. [CrossRef]

79. Mikami, Y.; Yazawa, K.; Fukushima, K.; Arai, T.; Samson, R.A. Paecilotoxin production in clinical or terrestrial isolates of Paecilomyces lilacinus strains. Mycopathologia 1989, 108, 195-199. [CrossRef]

80. Araujo, J.M.; Braga, F.R.; de Araujo, J.V.; Rogério, O.C. Activity of nematophagous fungi Pochonia chlamydosporia and Paecilomyces lilacinus on Dipylidium caninum egg capsules. Rev. Do Inst. Adolfo Lutz 2009, 68, 488-491.

81. Mikami, Y.; Fukushima, K.; Arai, T.; Abe, F.; Ommura, Y. Leucinostatins, peptide mycotoxins produced by Paecilomyces lilacinus and their possible roles in fungal infection. Zent. Für Bakteriol. Mikrobiol. Hyg. 1984, 257, 275-283. [CrossRef]

82. Khan, A.; Williams, K.; Nevalainen, H. Testing the nematophagous biological control strain Paecilomyces lilacinus 251 for paecilotoxin production. FEMS Microbiol. Lett. 2003, 227, 107-111. [CrossRef]

83. Filho, F.; Pereira, D.; Vieira, J.N.; Berne, M.; Ptter, L. Fungal ovicidal activity on Toxocara canis eggs. Rev. Iberoam. Micol. 2013, 30, 226-230. [CrossRef] [PubMed]

84. Arias, M.S.; Cazapal-Monteiro, C.F.; Suarez, J.; Miguelez, S.; Francisco, I.; Arroyo, F.L.; Suarez, J.L.; Paz-Silva, A.; SanchezAndrade, R.; de Gives, P.M. Mixed production of filamentous fungal spores for preventing soil-transmitted helminth zoonoses: A preliminary analysis. BioMed Res. Int. 2013, 2013, 567876. [CrossRef]

85. Cazapal-Monteiro, C.F.; Hernández, J.; Arroyo, F.L.; Miguélez, S.; Arias, M.S. Analysis of the effect of soil saprophytic fungi on the eggs of Baylisascaris procyonis. Parasitol. Res. 2015, 114, 2443-2450. [CrossRef] [PubMed]

86. Canhao-Dias, M.; Paz-Silva, A.; de Carvalho, L.M.M. The efficacy of predatory fungi on the control of gastrointestinal parasites in domestic and wild animals-A systematic review. Vet. Parasitol. 2020, 283, 109173. [CrossRef]

87. De Gives, P.M.; Davies, K.G.; Clark, S.J.; Behnke, J.M. Predatory behaviour of trapping fungi against srf mutants of Caenorhabditis elegans and different plant and animal parasitic nematodes. Parasitology 1999, 119, 95-104. [CrossRef]

88. Wang, B.; Zhang, N.; Gong, P.T.; Li, J.; Yang, J.; Zhang, X.; Cai, K. Effect of temperature, pH, physical and chemical factors on germination rate of the chlamydospores of the nematophagous fungus Duddingtonia flagrans. FEMS Microbiol. Lett. 2019, 366, fnz212. [CrossRef]

89. Bird, J.; Herd, R.P. In-vitro assessment of a species of nematophagous fungi (Arthrobotrys-oligospora and Arthrobotrys-flagrans) to control the development of infetive cyathostome larvae from naturally infected horses. Vet. Parasitol. 1995, 56, 181-187. [CrossRef]

90. Silva, A.R.; Araújo, J.; Braga, F.R.; Benjamim, L.A.; Souza, D.L.; Carvalho, R.O. Comparative analysis of destruction of the infective forms of Trichuris trichiura and Haemonchus contortus by nematophagous fungi Pochonia chlamydosporia; Duddingtonia flagrans and Monacrosporium thaumasium by scanning electron microscopy. Vet. Microbiol. 2011, 147, 214-219. [CrossRef]

91. Matthews, J.B.; Hodgkinson, J.E.; Dowdall, S.; Proudman, C.J. Recent developments in research into the Cyathostominae and Anoplocephala perfoliata. Vet. Res. 2004, 35, 371-381. [CrossRef]

92. Vilela, V.; Feitosa, T.F.; Braga, F.R.; Araújo, J.; Souto, D.; Santos, H.; Silva, G.; Athayde, A. Biological control of goat gastrointestinal helminthiasis by Duddingtonia flagrans in a semi-arid region of the northeastern Brazil. Vet. Parasitol. 2012, 188, 127-133. [CrossRef] [PubMed] 
93. Vilela, V.; Feitosa, T.F.; Braga, F.R.; Araújo, J.; Lucena, S.; Dantas, E.S.; Athayde, A.; Silva, W.W. Efficacy of Monacrosporium thaumasium in the control of goat gastrointestinal helminthiasis in a semi-arid region of Brazil. Parasitol. Res. 2013, 112, 871-877. [CrossRef] [PubMed]

94. Tavela, A.O.; Araujo, J.V.; Braga, F.R.; Araujo, J.M.; Magalhaes, L.Q.; Silveira, W.F.; Borges, L.A. In vitro association of nematophagous fungi Duddingtonia flagrans (AC001), Monacrosporium thaumasium (NF34) and Pochonia chlamydosporia (VC1) to control horse cyathostomin (Nematoda: Strongylidae). Biocontrol Sci. Technol. 2012, 22, 607-610. [CrossRef]

95. Eduardo, S.M.; Ribeiro, B.F.; Mendoza, D.; Jair, M.O.; Mercado, U.; Aguilar, M.L.; Freitas, S.; Luiza, A.A.; Souza, V.T.; Rocha, A.A. Fungal antagonism assessment of predatory species and producers metabolites and their effectiveness on Haemonchus contortus infective larvae. BioMed Res. Int. 2015, 22, 1-6. [CrossRef]

96. Silva, M.; Braga, F.R.; Gives, P.; Uriostegui, M.; Reyes, M.; Soares, F.; Carvalho, L.; Rodrigues, F.B.; Araújo, J. Efficacy of Clonostachys rosea and Duddingtonia flagrans in reducing the Haemonchus contortus infective larvae. BioMed Res. Int. 2015, 2015, 10-14. [CrossRef]

97. Silveira, W.F.D.; Oliveira, G.D.D.; Braga, F.R.; Carvalho, L.M.D.; Domingues, R.R.; Silva, L.A.D.; Zanuncio, J.C.; Araújo, J.V.D. Predation rate of nematophagous fungi after passing through the gastrointestinal tract of goats. Small Rumin. Res. 2017, 147, 101-105. [CrossRef]

98. Fernandes, F.M.; Aguiar, A.R.; Silva, L.P.C.; Senna, T.; de Mello, I.N.K.; de Oliveira, T.; Freitas, S.G.; Silveira, W.F.; Braga, F.R.; Araujo, J.V. Biological control on gastrointestinal nematodes in cattle with association of nematophagous fungi. Biocontrol Sci. Technol. 2017, 27, 1445-1453. [CrossRef]

99. Tavela, A.; Araújo, J.D.; Braga, F.R.; Silveira, W.; Herold, D.; Júnior, M.C.; Borges, L.A.; Araujo, J.M.; Benjamin, L.; Carvalho, G.R. Coadministration of sodium alginate pellets containing the fungi Duddingtonia flagrans and Monacrosporium thaumasium on cyathostomin infective larvae after passing through the gastrointestinal tract of horses. Res. Vet. Sci. 2013, 94, 568-572. [CrossRef]

100. Tiago, D.; Monteiro, T.; Braga, F.R.; Elias, D.; Mello, I.D.; Araujo, J.M.; Freitas, L.D.; Araújo, J.D. Assessment of compatibility between the nematophagous fungi Arthrobotrys robusta and Duddingtonia flagrans under laboratory conditions. Rev. Iberoam. Micol. 2016, 33, 129-130. [CrossRef]

101. Soares, F.B.; Monteiro, A.C. Compatibilidade de Metarhizium anisopliae com carrapaticidas qumicos. Arq. Do Inst. Biológico 2011, 78, 385-391. [CrossRef]

102. Palomero, A.M.; Cazapal-Monteiro, C.F.; Vina, C.; Hernandez, J.A.; Voinot, M.; Vila, M.; Silva, M.I.; Paz-Silva, A.; SanchezAndrade, R.; Arias, M.S. Formulating fungal spores to prevent infection by trichostrongylids in a zoological park: Practical approaches to a persisting problem. Biol. Control 2021, 152, 104466. [CrossRef]

103. Silva, M.; Braga, F.R.; Borges, L.A.; Oliveira, J.; Lima, W.; Guimarães, M.; Araújo, J. Evaluation of the effectiveness of Duddingtonia flagrans and Monacrosporium thaumasium in the biological control of gastrointestinal nematodes in female bovines bred in the semiarid region. Vet. Res. Commun. 2014, 38, 101-106. [CrossRef] [PubMed]

104. Ferraz, C.M.; Sobral, S.A.; Senna, C.C.; Fidelis, O.; Moreira, T.F.; Tobias, F.L.; Soares, F.E.D.; Genier, H.L.A.; Vilela, V.L.R.; Lima, J.A.C.; et al. Combined use of ivermectin, dimethyl sulfoxide, mineral oil and nematophagous fungi to control Rhabditis spp. Vet. Parasitol. 2019, 275, 108924. [CrossRef] [PubMed]

105. Ribeiro, V.; Ferreira, F.T.; Ribeiro, B.F.; Diniz, V.V.; De, L.; De, A. Control of sheep gastrointestinal nematodes using the combination of Duddingtonia flagrans and Levamisole Hydrochloride 5\%. Rev. Bras. Parasitol. Vet. 2018, 27, 27-32. [CrossRef]

106. Wang, B.; Zhang, N.; Gong, P.; Li, J.; Wang, X.; Li, X.; Wang, F.; Cai, K.; Zhang, X. In vitro assays on the susceptibility of four species of nematophagous fungi to anthelmintics and chemical fungicides/antifungal drug. Lett. Appl. Microbiol. 2021, 73, 124-131. [CrossRef] [PubMed]

107. Vieira, J.N.; Filho, F.M.; Ferreira, G.F.; Mendes, J.F.; Gonçalves, C.; Villela, M.M.; Pereira, D.; Nascente, P.S. In vitro susceptibility of nematophagous fungi to antiparasitic drugs: Interactions and implications for biological control. Braz. J. Biol. 2016, 77, 476-479. [CrossRef]

108. Sanyal, P.K.; Chauhan, J.B.; Mukhopadhyaya, P.N. Implications of fungicidal effects of Benzimidazole compounds on Duddingtonia flagrans in integrated nematode parasite management in livestock. Vet. Res. Commun. 2004, 28, 375-385. [CrossRef]

109. Silva, A.R.; Araujo, J.V.; Braga, F.R.; Alves, C.D.F.; Frassy, L.N. Activity in vitro of fungal conidia of Duddingtonia flagrans and Monacrosporium thaumasium on Haemonchus contortus infective larvae. J. Helminthol. 2011, 85, 138-141. [CrossRef]

110. Williams, A.C.; Barry, B.W. Penetration enhancers. Adv. Drug Deliv. Rev. 2004, 56, 603-618. [CrossRef]

111. Singh, R.K.; Sanyal, P.K.; Patel, N.K.; Sarkar, A.K.; Santra, A.K.; Pal, S.; Mandal, S.C. Fungus-benzimidazole interactions: A prerequisite to deploying egg-parasitic fungi Paecilomyces lilacinus and Verticillium chlamydosporium as biocontrol agents against fascioliasis and amphistomiasis in ruminant livestock. J. Helminthol. 2010, 84, 123-131. [CrossRef]

112. Wu, B.; Hussain, M.; Zhang, W.; Stadler, M.; Liu, X.; Xiang, M. Current insights into fungal species diversity and perspective on naming the environmental DNA sequences of fungi. Mycology 2019, 10, 127-140. [CrossRef] [PubMed]

113. Xu, J.P. Fungal species concepts in the genomics era. Genome 2020, 63, 459-468. [CrossRef] [PubMed]

114. Nordbring-Hertz, B.; Jansson, H.-B.; Tunlid, A. Nematophagous fungi. In Encyclopedia of Life Sciences; Wiley \& Sons: New York, NY, USA, 2006; p. 0004293. 